\title{
Analisis Dampak Reviu Inspektorat terhadap Kualitas Akuntabilitas Laporan Keuangan Pemerintah Daerah (LKPD) Kab. Minahasa Tenggara TA 2010 dan 2011
}

\author{
Oleh: \\ Agus Prasetyo \\ Sifrid S. Pangemanan \\ Program Pendidikan Profesi Akuntansi \\ Fakultas Ekonomi dan Bisnis \\ Universitas Sam Ratulangi Manado \\ Email: prazztied@gmail.com
}

\begin{abstract}
ABSTRAK
Penelitian ini bertujuan untuk mengetahui mekanisme reviu Laporan Keuangan Pemerintah Daerah oleh Inspektorat Kabupaten Minahasa Tenggara pada setiap tahap perencanaan pelaksanaan dan pelaporan. Berdasarkan hasil penelitian ini, pelaksanaan reviu LKPD oleh Inspektorat Tahun Anggaran 2010 dan 2011 belum memberikan dampak signifikan terhadap peningkatan akuntabilitas LKPD. Pemerintah Daerah Kabupaten Minahasa Tenggara harus menyiapkan langkah-langkah perbaikaan mekanisme reviu pada setiap tahap perencaanaan, pelaksanaan dan pelaporan dengan mengikuti standar pedoman reviu (Peraturan Menteri Dalam Negeri Nomor 4 Tahun 2008), pendidikan dan pelatihan tenaga Inspektorat melalui koordinasi dengan BPKP, pemenuhan kuantitas, kualitas dan standar SDM Inspektorat serta identifikasi setiap permasalahan yang telah menyebabkan disclaimer opinion LKPD TA 2010 dan 2011 sebagai prioritas penentuan langkah perbaikan melalui koordinasi dengan pihak DPPKAD dan BPK RI.

Kata Kunci : Reviu Inspektorat, Akuntabilitas, Laporan Keuangan Pemerintah Daerah (LKPD)

ABSTRACT

This study aims to determine the mechanism of review of financial statements the Government Financial Reportby InspektoratKab. Minahasa Tenggara at every stage of planning, execution and reporting. Based on these results, the implementation of Review LKPD by Inspektorat for Year 2010 and 2011 has not been a significant impact on increasing accountability LKPD. The Goverment Minahasa Tenggara should prepare measures improvement review of mechanisms at each stage planning, execution and reporting standards by following the guideline of Review (Peraturan Menteri Dalam Negeri No. 4 Tahun 2008), the education and training Inspektorat personnel in coordination with BPK, fulfillment quantity, human resources and quality standards as well as the identification of any problems Inspektorat which has led disclaimer opinions LKPD year 2010 and 2011 as a priority determining corrective actions in coordination with the DPPKAD and BPK RI.
\end{abstract}

Keywords: Review Inspektorat, Accountability, Government Finance Report (LKPD) 


\section{A. PENDAhuluan}

Reformasi Keuangan Negara di Indonesia adalah dengan ditetapkannya ketiga paket Undang-Undang (UU) terkait Pengelolaan Keuangan Negara yaitu UU Nomor 17 Tahun 2003 tentang Keuangan Negara, UU Nomor 1 Tahun 2004 tentang Perbendaharaan Negara dan UU Nomor 15 Tahun 2004 tentang Pemeriksaan Pengelolaan dan Tanggung Jawab Keuangan Negara. Keuangan negara adalah semua hak dan kewajiban negara yang dapat dinilai dengan uang, serta segala sesuatu baik berupa uang maupun berupa barang yang dapat dijadikan milik negara berhubung dengan pelaksanaan hak dan kewajiban tersebut. Salah satu wujud keuangan negara adalah pengelolaan Anggaran Pendapatan Belanja Negara (APBN) dan Anggaran Pendapatan Belanja Daerah (APBD).

Ketiga paket UU tersebut selanjutnya dijabarkan melalui peraturan perundang-undangan dibawahnya yang akan menjadi pedoman bagi Pemerintah Pusat dan Pemerintah Daerah dalam melaksanakan Tata Kelola Keuangan Negara/Daerah melalui APBN/APBD. Pelaksanaan APBD tersebut akan menghasilkan Laporan Keuangan Pemerintah Daerah (LKPD) untuk selanjutnya diserahkan kepada BPK RI agar dilakukan pemeriksaan keuangan yang menghasilkan "opini" sebelum dipertanggungjawabkan kepada DPRD.

Sesuai dengan Peraturan Pemerintah (PP) Nomor 8 Tahun 2006 tentang Pelaporan Keuangan dan Kinerja Pemerintah dijelaskan bahwa Pemerintah dapat memaksimalkan peran Aparat Pengawasan Intern Pemerintah (APIP) pada Kementerian Negara/Lembaga/pemerintah daerah untuk melakukan "review atas Laporan Keuangan" dalam rangka meyakinkan keandalan informasi yang disajikan pada Laporan Keuangan sebelum disampaikan oleh Menteri/Pimpinan Lembaga/gubernur/bupati/walikota kepada pihak-pihak terkait seperti Badan Pemeriksa Keuangan (BPK).

Berdasarkan data Ikhtisar Hasil Pemeriksaan Semesteran (IHPS) di Tahun 2008 s.d. 2011 pada BPK RI diketahui Pemerintah Daerah seluruh Indonesia yang memperoleh opini WTP ratarata hanya $6,46 \%$ dari total pemerintah daerah. Hal ini menunjukkan masih rendahnya tingkat kualitas akuntabilitas LKPD. Opini terhadap LKPD Tahun Anggaran (TA) 2008 s.d 2011 pada Pemerintah Kabupaten Minahasa Tenggara adalah Opini ”Disclaimer” dari BPK RI.

Hal tersebut menjadi perhatian bagi penulis sehingga tertarik untuk melakukan analisis lebih lanjut mengenai dampak reviu Inspektorat Kabupaten Minahasa Tenggara terhadap kualitas LKPD Kabupaten Minahasa Tenggara terkait dengan Opini yang telah diberikan oleh BPK RI. Penulis melakukan analisis apakah reviu Inspektorat berjalan sebagaimana mestinya sesuai harapan dari pemerintah dan masyarakat yang nantinya akan meningkatkan akuntabilitas atau pertanggungjawaban keuangan negara/daerah. Penulis ingin melihat bagaimana mekanisme reviu yang telah dilakukan Inspektorat guna dapat memberikan masukan dan saran perbaikan di masa yang akan datang.

Berdasasarkan latar belakang di atas, dapat dirumuskan permasalahan sebagai berikut.

1. Bagaimana proses atau mekanisme pelaksanaan reviu Inspektorat terhadap Laporan Keuangan Pemerintah Daerah Tahun Anggaran 2010 dan 2011 pada Kabupaten Minahasa Tenggara?

2. Bagaimana dampak reviu Inspektorat terhadap peningkatan akuntabilitas Laporan Keuangan Pemerintah Daerah Tahun Anggaran 2010 dan 2011 pada Kabupaten Minahasa Tenggara?

3. Langkah-langkah apa yang telah dilakukan oleh Pemerintah Kabupaten Minahasa Tenggara untuk meningkatkan kualitas akuntabilitas Laporan Keuangan Pemerintah Daerah? 


\section{A. TINJAUAN PUSTAKA (KERANGKA TEORITIS)}

\section{Akuntansi Keuangan Daerah}

Akuntansi Keuangan Daerah adalah suatu disiplin ilmu yang menyediakan informasi yang diperlukan oleh entitas pemerintah daerah dalam melaksanakan kegiatannya secara efisien dan mengevaluasi kegiatan-kegiatan untuk menghasilkan suatu laporan keuangan yang akan menjadi dasar stakeholders dalam pengambilan keputusan.

\section{Tinjauan Umum Tentang Akuntansi Keuangan Daerah}

Pada dasarnya Akuntansi terdiri dari tiga bagian utama yaitu Akuntansi komersil perusahaan (commercial accounting), Akuntansi pemerintahan (govermental accounting) dan Akuntansi sosial (social accounting). Kedudukan Akuntansi Keuangan Daerah merupakan salah satu cabang dari Akuntansi pemerintahan tersebut.

Tujuan Akuntansi Keuangan Daerah diantaranya memberikan informasi keuangan sebagai bahan pengambilan keputusan para stakeholders, alat pertanggungjawaban, manajerial dan pengawasan. Para stakeholderstersebutantara lain DPRD (Dewan Perwakilan Rakyat Daerah), BPK (Badan Pengawas Keuangan), Investor, Kreditor, dan Donatur, Analisis ekonomi dan pemerhati Pemerintah Daerah, Rakyat, Pemerintah Pusat dan Pemerintah Daerah (Kabupaten, Kota, dan Propinsi).

\section{Laporan Keuangan Pemerintah Daerah}

Laporan keuangan merupakan laporan yang terstruktur mengenai posisi keuangan dan transaksitransaksi yang dilakukan oleh suatu entitas pelaporan. Tujuan umum laporan keuangan adalah menyajikan informasi mengenai posisi keuangan, realisasi anggaran, arus kas, dan kinerja keuangan suatu entitas pelaporan yang bermanfaat bagi para pengguna dalam membuat dan mengevaluasi keputusan mengenai alokasi sumber daya.

Komponen Laporan Keuangan Pemerintah Daerah antara lain Neraca, Laporan Realisasi Anggaran, Laporan Arus Kas dan Catatan Atas Laporan Keuangan. Komponen-komponen laporan keuangan tersebut disajikan oleh setiap entitas pelaporan, kecuali Laporan Arus Kas (LAK) yang hanya disajikan oleh unit yang mempunyai fungsi perbendaharaan.

\section{Reviu Laporan Keuangan Pemerintah Daerah}

Reviu adalah prosedur penelusuran angka-angka dalam laporan keuangan, permintaan keterangan, dan analitik yang harus menjadi dasar memadai bagi Aparat Pengawasan Intern Pemerintah (APIP) untuk memberi keyakinan terbatas bahwa tidak ada modifikasi material yang harus dilakukan atas laporan keuangan agar laporan keuangan tersebut sesuai dengan Standar Akuntansi Pemerintahan. Review atas laporan keuangan dilakukan dalam rangka penyusunan pernyataan tanggung jawab (statement of responsibility) atas laporan keuangan. Pernyataan tanggung jawab tersebut menyatakan bahwa laporan keuangan telah disusun berdasarkan sistem pengendalian intern yang memadai dan sesuai dengan standar akuntansi pemerintahan (SAP).

\section{Aparat Pengawasan Intern Pemerintah (APIP)}

APIP adalah Instansi Pemerintah yang mempunyai tugas pokok dan fungsi melakukan pengawasan, dan terdiri atas Badan Pengawasan Keuangan dan Pembangunan (BPKP) yang bertanggung jawab kepada Presiden, Inspektorat Jenderal (Itjen)/Inspektorat Utama (Ittama)/Inspektorat yang bertanggung jawab kepada Menteri/Kepala Lembaga Pemerintah Non Departemen (LPND), Inspektorat Pemerintah Provinsiyang bertanggung jawab kepada Gubernur, dan Inspektorat Pemerintah Kabupaten/Kota yang bertanggung jawab kepada Bupati/Walikota. Tugas dan Fungsi APIP menurut PP 60 Tahun 2008 yaitu melakukan pengawasan internmelalui Audit, terdiri atas Audit Kinerja dan Audit dengan Tujuan Tertentu, Reviu, Evaluasi, Pemantauan, dan Kegiatan Pengawasan Lainnya.

\section{Sistem Pengendalian Intern Pemerintah (SPIP)}


Pasal 2 ayat (1) PP Nomor 60 Tahun 2008 menyatakan bahwa untuk mencapai pengelolaan keuangan negara yang efektif, efesien, transparan, dan akuntabel, menteri/pimpinan lembaga, gubernur, dan bupati/walikota wajib melakukan pengendalian atas penyelenggaraan kegiatan pemerintah. Pengendalian tersebut berpedoman pada SPIP. Unsur-unsur SPIP terdiri dari Lingkungan Pengendalian, Penilaian Risiko, Kegiatan Pengendalian, Informasi dan Komunikasi dan Pemantauan Pengendalian Intern.

\section{B. METODE PENELITIAN Prosedur Penelitian}

Penelitian pada studi kasus ini menggunakan pendekatan penelitian kualitatif. Hal ini dikarenakan pada penelitian ini akan menghasilkan dan mengolah data yang sifatnya deskriptif, seperti analisa peraturan, analisa dokumen dari sumber penelitian, transkripsi wawancara, dan lain-lain. Melalui penelitian ini diharapkan dapat mendapatkan informasi yang selengkap mungkin mengenai dampak dari reviu LKPD TA 2010 dan TA 2011 oleh Inspektorat terhadap kualitas Akuntabilitas LKPD pada Pemerintah Daerah Kabupaten Minahasa Tenggara.

\section{Jenis dan Sumber Data}

Berdasarkan bentuk dan sifatnya, data penelitian dapat dibedakan dalam dua jenis yaitu data kualitatif (yang berbentuk kata-kata/kalimat) dan data kuantitatif (yang berbentuk angka). Adapun jenis data yang digunakan dalam penelitian ini adalah data kualitatif yang berbentuk kata-kata, bukan dalam bentuk angka. Data kualitatif diperoleh melalui berbagai macam teknik pengumpulan data yaitu wawancara, analisis dokumen, diskusi terfokus, atau observasi.

Sumber data yang dipakai dalam penelitian ini adalah data primer yaitu data yang dikumpulkan secara langsung dari obyek yang diteliti (data-data dari hasil wawancara dengan Kepala Inspektorat, Kepala Dinas Pendapatan, Pengelolaan, Keuangan dan Aset Daerah) dan data sekunder yaitu data yang diperoleh tidak dari sumbernya langsung melainkan sudah dikumpulkan oleh pihak lain dan sudah diolah (Visi Misi Pemerintah Daerah Kabupaten Minahasa Tenggara, Struktur Organisasi Inspektorat Kabupaten Minahasa Tenggara, Tujuan Pokok Fungsi dan Tugas Inspektorat Pemerintah Daerah Kabupaten Minahasa Tenggara, Laporan Hasil Pelaksanaan Reviu LKPD TA 2010 dan TA 2011, Laporan Hasil Pemeriksaan BPK RI atas LKPD Kabupaten Minahasa Tenggara TA 2010 dan TA 2011).

\section{Tempat dan Waktu Penelitian}

Tempat Penelitian dari penelitian ini adalah Inspektorat Daerah Kabupaten Minahasa Tenggara yang terletak di Jalan Raya Ratahan Kompleks Perkantoran Bupati Minahasa Tenggara Blok A Kelurahan Pasan Kec. Ratahan Kab. Minahasa Tenggara.

Penelitian ini keseluruhan dilaksanakan mulai 4 November sampai 9 November 2012 selama satu minggu atau lima hari kerja.

\section{PEMBAHASAN}

1. Reviu LKPD TA 2010

\section{a. Perencanaan}

Inspektorat Pemerintah Kabupaten Minahasa Tenggara telah melakukan proses perencanaan reviu LKPD Kabupaten Minahasa Tenggara Tahun Anggaran 2010. Dalam melaksanakan proses perencanaan reviu tersebut masih terdapat beberapa hal yang belum dapat dilaksanakan secara optimal untuk mendukung pelaksanaan reviu, secara lebih detail diuraikan sebagai berikut.

\section{1). Pemahaman atas Entitas}

Proses pemahaman atas entitas telah dilaksanakan antara lain dengan pengumpulan berita atau informasi terkait dengan pengelolaan keuangan Pemerintah Kabupaten Minahasa Tenggara 
selama TA 2010. Selan itu, Inspektorat yang merupakan salah satu Satuan Kerja Perangkat Daerah (SKPD) di lingkungan Pemerintah Kabupaten Minahasa Tenggara, mengakibatkan baik secara langsung maupun tidak langsung telah dapat mengidentifikasi informasi-informasi pelaksanaan keuangan daerah selama TA 2010.

Namun dalam pelaksanaan pemahaman atas entitas tersebut terdapat beberapa hal yang tidak dapat dilaksanakan secara optimal antara lain:

a). Pemerintah Kabupaten Minahasa Tenggara selama TA 2010 belum memiliki Peraturan Bupati tentang Sistem dan Prosedur (Sisdur) Pengelolaan Keuangan Daerah. Hal ini berdampak pada pemahaman atas entitas hanya dapat dilaksankan melalui pemahaman alur atau tahap-tahap dalam transaksi keuangan selama TA 2010. Oleh karena itu, pemahaman entitas tidak dapat dilaksanakan dan dianalisa dengan memadai. Pemahaman atas transaksi hanya dilakukan melalui wawancara terhadap pihak terkait.

b). Pemerintah Kabupaten Minahasa Tenggara selama TA 2010 belum memiliki Peraturan Bupati tentang Kebijakan Akuntansi dan Pelaporan Keuangan. Hal ini berdampak pada proses pemahaman atas penyusunan, penyajian dan pengungkapan pada LKPD TA 2010 tidak dapat dianalisa untuk dibandingkan dengan LKPD sebelum reviu yang telah disusun oleh Dinas Pengelolaan Pendapatan dan Keuangan Daerah (DPPKAD). Pemahaman atas hal tersebut hanya dapat dilakukan melalui tanya jawab dengan pihak-pihak terkait tentang proses akuntansi, membaca laporan keuangan entitas dan membaca kertas kerja reviu entitas periode sebelumnya.

\section{2). Pemahaman atas Pengendalian Intern (SPI)}

Proses pemahaman atas SPI sesuai dengan Peraturan Menteri Dalam Negeri Nomor 4 Tahun 2008 tentang Pedoman Pelaksanaan Reviu LKPD terdiri atas memahami sistem dan prosedur pengelolaan keuangan daerah, melakukan observasi dan/atau wawancara dengan pihak terkait di setiap prosedur yang ada, melakukan analisis atas resiko yang telah diidentifikasi pada sebuah kesimpulan tentang kemungkinan terjadinya salah saji yang material dalam penyusunan laporan keuangan dan melakukan analisis atas resiko yang telah diidentifikasi pada sebuah kesimpulan tentang arah pelaksanaan reviu.

Keseluruhan tahapan proses pemahaman SPI tidak dapat dilaksanakan sepenuhnya oleh Inspektorat Kabupaten Minahasa Tenggara dikarenakan keterbatasan jumlah sumber daya manusia di Inspektorat (pegawai hanya 24 orang termasuk pejabat struktural) dan jumlah waktu yang diberikan dalam penugasan reviu LKPD TA 2010. Waktu yang diberikan sebanyak 14 (empat belas) hari belum dapat mengakomodir keseluruhan tahapan reviu baik perencanaan, pelaksanaan dan pelaporan reviu LKPD TA 2010.

\section{3). Penyusunan Program Kerja Reviu}

Program Kerja Reviu atas LKPD TA 2010 belum dilaksanakan oleh Inspektorat. Hal ini berdampak terhadap proses pelaksanaan reviu menjadi tidak terarah dan belum dapat menjawab tujuan reviu LKPD TA 2010.

\section{b. Pelaksanaan}

Sesuai dengan Peraturan Menteri Dalam Negeri Nomor 4 Tahun 2008 tentang Pedoman Pelaksanaan Reviu LKPD, pelaksanaan reviu dilaksanakan oleh tim secara paralel dengan proses penyusunan LKPD. Reviu tersebut dilaksanakan paling lambat 2 (dua) bulan setelah tahun anggaran berakhir. Kegiatan-kegiatan dalam proses pelaksanaan tersebut meliputi penelusuran angka, permintaan keterangan dan prosedur analitis.

Proses pelaksanaan reviu oleh Inspektorat terhadap LKPD TA 2010 dilaksanakan pada bulan Juli 2011. Hal ini tidak sesuai dengan Pedoman Pelaksanaan Reviu yang harus dilaksanakan paling lambat pada Bulan Februari tahun anggaran berikutnya. 
Keterlambatan tersebut dikarenakan pelaksanaan reviu LKPD TA 2010 tidak dilaksanakan secara paralel dengan penyusunan LKPD. Reviu oleh Inspektorat Kabupaten Minahasa Tenggara dilaksanakan setelah Laporan Keuangan selesai disusun oleh DPPKAD. LKPD yang telah selesai disusun oleh DPPKAD tersebut selanjutnya dilakukan reviu oleh Inspektorat. Setelah reviu dilaksanakan, maka LKPD tersebut disesuaikan oleh DPPKAD berdasarkan catatan-catatan pada Laporan hasil reviu. Proses selanjutnya adalah LKPD yang telah dilakukan perbaikan tersebut diserahkan kepada BPK RI untuk dilakukan pemeriksaan dan dilakukan pemberian Opini atas hasil pemeriksaan oleh BPK RI.

\section{c. Pelaporan}

Hasil pelaksanaan Reviu LKPD TA 2010 telah disampaikan oleh Inspektur kepada Bupati Minahasa Tenggara melalui Surat Nomor 63A/INSP/ST/700/VI-2011 tanggal 25 Juni 2011. Laporan tersebut terdiri atas Pernyataan Reviu, Dasar Reviu, Tujuan dan Sasaran Reviu, Ruang Lingkup Reviu, Simpulan dan Rekomendasi serta Tindak Lanjut Hasil Reviu Sebelumnya. Penjelasan terhadap struktur laporan reviu sebagai berikut.

\section{1). Pernyataan Reviu}

Reviu dilakukan Inspektorat terhadap LKPD TA 2010 berupa Neraca per 31 Desember 2010, LRA, LAK dan Catatan Atas Laporan Keuangan untuk periode yang berakhir pada tanggal tersebut.

Inspektorat melaksanakan reviu dengan mengacu pada Permendagri Nomor 4 Tahun 2008 tentang Pedoman Reviu LKPD. Reviu yang telah dilakukan mencakup permintaan penjelasan kepada pejabat entitas pelaporan/PPKD dan entitas pengguna/SKPD serta prosedur analitik yang diterapkan atas data keuangan.

Berdasarkan reviu tersebut, Inspektorat menyatakan terdapat beberapa penyebab yang mengakibatkan Laporan Keuangan tidak dapat diyakini yaitu Laporan Keuangan belum sepenuhnya disajikan berdasarkan sistem pengendalian yang memadai dan sesuai Standar Akuntansi Pemerintahan. Hal tersebut dikarenakan sebagai berikut.

a). Terdapat perbedaan antara kenaikan Kas di Neraca dengan kenaikan SILPA Neraca dan kenaikan Utang Perhitungan Fihak Ketiga (PFK). Perbedaan tersebut belum dijelaskan dalam Catatan Atas Laporan Keuangan (CaLK).

b). Terdapat perbedaan nilai Belanja Modal pada LRA dengan kenaikan Aset pada Neraca. Perbedaan tersebut belum dijelaskan dalam CaLK.

c). Bidang Pendapatan belum memiliki data PAD dan penerimaan lainnya sehingga tidak dapat dilakukan rekonsiliasi antara Bendahara Penerimaan dan Bidang Pendapatan serta Bidang Akuntansi.

d). Belum adanya data aset Pemerintah Kabupaten Minahasa Tenggarayang telah menjadi daerah otonom sampai saat ini sehingga tidak dapat dilakukan rekonsiliasi antara data aset pada Bidang Aset dengan Bidang Akuntansi.

\section{2). Dasar Reviu}

Inspektorat melaksanakan Reviu LKPD berdasarkan Peraturan Pemerintah Nomor 8 Tahun 2006 tentang Pelaporan Keuangan dan Kinerja Instansi Pemerintah dan Permendagri Nomor 4 Tahun 2008 tentang Pedoman Pelaksanaan Reviu atas Laporan Keuangan Pemerintah Daerah.

\section{3). Tujuan dan Sasaran Reviu}

Tujuan reviu adalah untuk memberikan keyakinan terbatas atas laporan keuangan yang disajikan berdasarkan Sistem Pengendalian Intern yang memadai dan kesesuaiannya dengan Standar Akuntansi Pemerintahan. Sasaran reviu adalah Laporan Keuangan yang disajikan oleh Pejabat Pengelola Keuangan Daerah (PPKD) mencakup Neraca, LRA, LAK dan CaLK.

\section{4). Ruang Lingkup Reviu}


Ruang Lingkup Reviu adalah penelaahan keandalan sistem pengendalian intern dalam penyajian laporan keuangan dan kesesuaian laporan keuangan dengan Standar Akuntansi Pemerintah.

\section{5). Simpulan dan Rekomendasi}

Terdapat beberapa catatan sebagai simpulan hasil reviu berupa adanya selisih kenaikan kas dengan selisih kenaikan SILPA Neraca dan Utang PFK Neraca, selisih perhitungan penambahan Aset Tetap di Neraca dengan Belanja Modal pada LRA maupun data pada Bidang Aset, data pendukung Pendapatan Asli Daerah (PAD) melalui Bendahara Penerimaan yang kurang memadai, pencatatan Piutang belum didukung Surat Keterangan Tanggung Jawab Mutlak (SKTJM) dari pejabat yang bertanggungjawab, pencatatan Aset Tetap-Konstruksi Dalam Pengerjaan (KDP) pada Neraca belum seluruhnya dilaporkan dan Penyusunan LK-SKPD masih terpusat melalui PPKD.

Dari beberapa catatan tersebut, Inspektorat menyarankan sebagai berikut.

a). Memerintahkan kepada Kepala DPPKAD untuk melakukan koreksi penambahan pengungkapan atas perbedaan kenaikan Kas dengan kenaikan SILPA dan Utang PFK pada CaLK.

b). Memerintahkan kepada Kepala DPPKAD untuk menelusur kembali pencatatan Aset, menelusur kembali perbedaan antara Belanja Modal pada LRA dengan kenaikan Aset Tetap pada Neraca per 31 Desember 2010.

c). Memerintahkan kepada Kepala bidang Pendapatan pada DPPKAD untuk melakukan pendataan data objek pajak, melakukan rekonsiliasi antara data penerimaan melalui Bendahara Penerimaan SKPD, data penerimaan Bidang Pendapatan DPPKAD dan data penerimaan pada Bidang Akuntansi.

d). Memerintahkan kepada Bendahara Penerimaan SKPD untuk menyampaikan laporan pertanggungjawaban penerimaan baik secara administratif maupun secara fungsional.

e). Memerintahkan PPK SKPD agar membuat Laporan Keuangan SKPD berupa Neraca, LRA dan CaLK SKPD pada masing-masing SKPD untuk selanjutnya dikompilasi di DPPKAD.

f). Tindak Lanjut Hasil Reviu Sebelumnya

Tidak terdapat hasil reviu LKPD TA 2009 yang belum ditindaklanjuti.

Korelasi Hasil Reviu Dengan Akuntabilitas LKPD TA 2010

LKPD TA 2010 Pemerintah Kabupaten Minahasa Tenggara telah dilakukan reviu oleh Inspektorat. LKPD hasil reviu tersebut selanjutnya dilakukan perbaikan oleh DPKAD sesuai dengan saran hasil reviu Inspektorat. LKPD yang telah dilakukan perbaikan selanjutnya disampaikan kepada BPK RI melalui Kepala Daerah.

BPK RI telah melakukan pemeriksaan LKPD TA 2010 Pemerintah Kabupaten Minahasa Tenggara. Hasil pemeriksaan tersebut memuat Opini "Tidak Memberikan Pendapat" atau Disclaimer Opinion. Permasalahan secara garis besar dalam Laporan Hasil Pemeriksaan tersebut adalah sebagai berikut:

a. Pengendalian intern atas pelaksanaan APBD meliputi prosedur penganggaran, pelaksanaan anggaran, dan pengeluaran Kas Daerah lemah dan tidak dilaksanakan sesuai dengan peraturan perundangan sehingga terdapat belanja diluar mekanisme APBD.

b. Penyajian Persediaan pada Neraca TA 2010 merupakan angka yang didapat bukan dari hasil inventarisasi fisik. Dokumen pendukung penyajian Persediaan tersebut belum diadministrasikan secara memadai.

c. Penyajian Aset Tetap pada Neraca TA 2010 belum menggambarkan kondisi sebenarnya dimana terdapat indikasi Belanja Modal TA 2009 yang belum dibukukan pada Neraca TA 2009 maupun TA 2010 dan saldo Aset Tetap yang disajikan pada Neraca belum seluruhnya didukung dengan rincian data yang memadai dalam daftar aset. 
d. Penyajian SiLPA pada Neraca TA 2010 belum didukung secara memadai dan tidak sesuai dengan pencatatan pada Buku Besar Pembantu.

e. Penyajian Utang Jangka Pendek Lainnya pada Neraca TA 2010 terdapat sisa Utang Jangka Pendek Lainnya yang berasal dari TA 2007 dan TA 2008 yang tidak didukung dengan dokumen memadai dan tidak dapat dijelaskan oleh Pemerintah Daerah.

Berdasarkan beberapa catatan dari Laporan Hasil Pemeriksaan LKPD TA 2010 tersebut, diantaranya telah diungkap pada Laporan Hasil Reviu LKPD TA 2010 Inspektorat berupa permasalahan pencatatan dan pengungkapan pada CaLK terkait akun Kas, SILPA dan Aset Tetap. Namun dikarenakan pelaksanaan reviu yang sudah terlambat dan waktu pelaksanaan reviu yang terbatas maka saran perbaikan Inspektorat belum dapat dilakukan sepenuhnya oleh Pemerintah Daerah khususnya DPPKAD.

Salah satu hal yang menjadikan DPPKAD tidak dapat melaksanakan saran hasil reviu adalah data pendukung laporan reviu yang kurang detail dan kurang lengkap menyulitkan DPPKAD untuk melakukan perbaikan Laporan Keuangan. Salah satu saran hasil reviu Inspektorat adalah DPPKAD diharuskan menelusur kembali pencatatan aset. Hal ini menyulitkan DPPKAD mengingat DPPKAD diharuskan segera menyelesaikan penyusunan LKPD untuk selanjutnya diserahkan BPK RI. LKPD hasil pemeriksaan BPK RI tersebut menjadi dokumen pertanggungjawaban Kepala Daerah kepada DPRD Kabupaten Minahasa Tenggara.

\section{Reviu LKPD TA 2011}

a. Perencanaan

Inspektorat Pemerintah Kabupaten Minahasa Tenggara telah melakukan proses perencanaan reviu LKPD Kabupaten Minahasa Tenggara Tahun Anggaran 2011. Dalam melaksanakan proses perencanaan tersebut masih terdapat beberapa hal yang belum dapat dilaksanakan secara optimal untuk mendukung pelaksanaan reviu, secara lebih detail diuraikan sebagai berikut:

1). Pemahaman atas Entitas

Proses pemahaman atas entitas telah dilaksanakan antara lain dengan pengumpulan berita atau informasi terkait dengan Pemerintah Kabupaten Minahasa Tenggara selama Tahun Anggaran 2011. Selan itu, Inspektorat yang merupakan salah satu Satuan Kerja Perangkat Daerah (SKPD) di lingkungan Pemerintah Kabupaten Minahasa Tenggara sehingga secara langsung maupun tidak langsung telah dapat mengidentifikasi informasi-informasi terkait pelaksanaan keuangan daerah selama Tahun Anggaran 2011.

Namun dalam pelaksanaan pemahaman atas entitas tersebut terdapat beberapa hal yang tidak dapat dilaksanakan secara optimal antara lain sebagai berikut.

a). Pemerintah Kabupaten Minahasa Tenggara selama Tahun Anggaran 2011 telah memiliki Peraturan Bupati tentang Sistem dan Prosedur Pengelolaan Keuangan Daerah. Namun hasil pemahaman atas Entitas, diketahui para pegawai di lingkungan Pemerintah Kabupaten Minahasa Tenggara belum mengetahui keberadaan dan bagaimana implementasi dari Peraturan Bupati tentang Sistem dan Prosedur Pengelolaan Keuangan tersebut. Hal ini terjadi dikarenakan kurangnya sosialisasi dan penjelasan dari DPPKAD terkait pelaksanaan peraturan bupati tersebut. Selain itu Sistem dan Prosedur yang telah ditetapkan tersebut belum mengakomodir secara detail dan penyelesaian permasalahan yang pernah ada seperti terkait pengelolaan Kas, Persediaan, Aset Tetap dan PAD.

b). Pemerintah Kabupaten Minahasa Tenggara selama Tahun Anggaran 2011 telah memiliki Peraturan Bupati tentang Kebijakan Akuntansi dan Pelaporan Keuangan.

Hasil pemahaman entitas terhadap Peraturan Bupati tentang Kebijakan Akuntansi tersebut diketahui belum mengakomodir permasalahan yang pernah ada di Pemerintah Daerah Minahasa Tenggara seperti permasalahan dan pengungkapan dalam LKPD terkait Akun Kas 
pada SKPD dan BUD, Piutang Lancar dan Piutang Non Lancar, Persediaan, Aset Tetap, Pendapatan dan Belanja Daerah. Dalam hal pengelolaan dan penyajian LKPD menggunakan aplikasi Sistem Manajemen Keuangan Daerah (SIMDA).

\section{2). Pemahaman atas Sistem Pengendalian Intern (SPI)}

Keseluruhan tahapan proses pemahaman SPI tidak dapat dilaksanakan sepenuhnya oleh Inspektorat Kabupaten Minahasa Tenggara dikarenakan keterbatasan sumber daya manusia (24 pegawai termasuk struktural) dan keterbatasan waktu yang diberikan dalam penugasan reviu LKPD TA 2011. Waktu yang diberikan untuk reviu selama 14 (empat belas) hari belum dapat mengakomodir keseluruhan tahapan perencanaan, pelaksanaan dan pelaporan reviu. Permasalahan ini masih sama dengan TA 2010 dan belum ada evalusasi dan solusi perbaikan terkait mekanisme reviu LKPD di Internal Inspektorat Kabupaten Minahasa Tenggara.

\section{3). Penyusunan Program Kerja Reviu}

Program Kerja Reviu atas LKPD TA 2011 belum dilaksanakan sepenuhnya oleh Inspektorat. Hal ini berdampak terhadap proses pelaksanaan reviu tidak terarah dan belum dapat menjawab tujuan proses reviu LKPD TA 2011. Permasalahan ini masih sama dengan reviu TA 2010, hal ini dikarenakan belum ada perbaikan mekanisme reviu LKPD oleh Inspektorat.

\section{b. Pelaksanaan}

Proses pelaksanaan reviu oleh Inspektorat terhadap LKPD TA 2011 dilaksanakan pada bulan Juli 2012. Hal ini dikarenakan reviu tersebut tidak dilaksaakan secara paralelmelainkan dilaksanakan setelah Laporan Keuangan selesai disusun oleh DPPKAD. Mekanisme reviu LKPD TA 2011 di Kabupaten Minahasa Tenggara adalah Laporan Keuangan disusun terlebih dahulu oleh DPPKAD untuk selanjutnya direviu oleh Inspektorat.

Permasalahan ini masih sama dengan pelaksanaan reviu LKPD TA 2010. Inspektorat Kabupaten Minahasa Tenggara belum melakukan evaluasi dan perbaikan terhadap mekanisme reviu LKPD.

\section{c. Pelaporan}

Hasil pelaksanaan Reviu LKPD TA 2011 telah disampaikan oleh Inspektur kepada Bupati Minahasa Tenggara melalui Surat Nomor 74A/INSP/ST/700/VI-2012 tanggal 30 Juli 2012. Laporan tersebut terdiri atas Pernyataan Reviu, Dasar Reviu, Tujuan dan Sasaran Reviu, Ruang Lingkup Reviu, Simpulan dan Rekomendasi serta Tindak Lanjut Hasil Reviu Sebelumnya. Penjelasan terhadap struktur laporan reviu sebagai berikut.

\section{1) Pernyataan Reviu}

Reviu dilakukan Inspektorat terhadap LKPD TA 2011 beupa Neraca per 31 Desember 2011, LRA, LAK dan CaLK untuk periode yang berakhir pada tanggal tersebut.

Inspektorat melaksanakan reviu dengan mengacu pada Permendagri Nomor 4 Tahun 2008 tentang Pedoman Reviu LKPD. Reviu yang dilakukan mencakup permintaan penjelasan kepada pejabat terkait pada entitas pelaporan/PPKD dan entitas pengguna/SKPD serta prosedur analitik yang diterapkan atas data keuangan.

Berdasarkan reviu tersebut, Inspektorat menyatakan terdapat penyebab yang mengakibatkan Laporan Keuangan tidak dapat diyakini bahwa sepenuhnya disajikan berdasarkan sistem pengendalian yang memadai dan sesuai SAP. Hal tersebut dikarenakan terdapat perbedaan data aset antara LRA dengan data Bidang Aset, perbedaan pada pos PFK dalam LAK dengan Neraca, selisih dalam pencatatan penambahan Aktiva Tetap antara Neraca dan LAK, belum adanya data PAD dan penerimaan lainnya pada Bendahara Penerimaan sehingga tidak dapat dilakukan rekonsiliasi antara Bendahara Penerimaan dan Bidang Akuntansi, serta belum adanya data asset Pemerintah Kabupaten Minahasa Tenggara yang menjadi daerah otonom sampai saat ini sehingga tidak dapat dilakukan rekonsiliasi antara Bidang Aset dengan Bidang Akuntansi.

\section{2) Dasar Reviu}


Inspektorat melaksanakan Reviu LKPD berdasarkan Peraturan Pemerintah Nomor 8 Tahun 2006 tentang Pelaporan Keuangan dan Kinerja Instansi Pemerintah, Permendagri Nomor 4 Tahun 2008 tentang Pedoman Pelaksanaan Reviu atas Laporan Keuangan Pemerintah Daerah dan Surat Tugas Nomor 005/700/18 Tahun 2012.

\section{3) Tujuan dan Sasaran Reviu}

Tujuan reviu adalah untuk memberikan keyakinan terbatas atas laporan keuangan yang disajikan berdasarkan Sistem Pengendalian Intern yang memadai dan kesesuaiannya dengan Standar Akuntansi Pemerintahan. Sasaran reviu adalah Laporan Keuangan yang disajikan oleh PPKD mencakup Neraca, LRA, LAK dan CaLK.

\section{4) Ruang Lingkup Reviu}

Ruang Lingkup Reviu adalah penelaahan keandalan sistem pengendalian intern dalam penyajian laporan keuangan dan kesesuaian laporan keuangan dengan SAP.

\section{5) Simpulan dan Rekomendasi}

Terdapat beberapa catatan sebagai simpulan hasil reviu berupa adanya selisih perhitungan penambahan Aset Tetap di Neraca dengan Belanja Modal pada LRA maupun data pada Bidang Aset, selisih PFK Neraca dengan LAK, data pendukung PAD melalui Bendahara Penerimaan yang kurang memadai, pencatatan Piutang namun belum didukung Surat Keterangan Tanggung Jawab Mutlak (SKTJM) dari pejabat yang bertanggungjawab, pencatatan Aset Tetap - Konstruksi Dalam Pengerjaan (KDP) pada Neraca belum seluruhnya dilaporkan dan Penyusunan LK-SKPD masih terpusat melalui PPKD.

Dari beberapa catatan tersebut, Inspektorat menyarankan sebagai berikut:

a). Memerintahkan kepada Kepala DPPKAD untuk menelusur kembali pencatatan Aset, PFK, pencatatan terhadap Aset KDP Dinas Dikpora dan menyusun Laporan Aset secara keseluruhan.

b). Memerintahkan kepada Bendahara Penerimaan SKPD untuk menyampaikan laporan pertanggungjawaban penerimaan baik secara administratif maupun secara fungsional, laporan pertanggungjawaban melalui Uang Persediaan/ Ganti Uang Persediaan.

c). Memerintahkan PPK SKPD agar membuat Laporan Keuangan SKPD berupa Neraca, LRA dan CALK SKPD untuk dikompilasi di PPKD.

6) Tindak Lanjut Hasil Reviu Sebelumnya

Tidak terdapat hasil reviu LKPD TA 2010 yang belum ditindaklanjuti.

\section{Korelasi Hasil Reviu Dengan Akuntabilitas LKPD TA 2011}

LKPD TA 2011 Pemerintah Kabupaten Minahasa Tenggara yang telah dilakukan reviu oleh Inspektorat selanjutnya dilakukan perbaikan oleh DPPKAD sesuai dengan saran hasil reviu Inspektorat. LKPD yang telah dilakukan perbaikan tersebut selanjutnya diserahan kepada BPK RI melalui Kepala Daerah.

BPK RI telah melakukan pemeriksaan LKPD TA 2011 Pemerintah Kabupaten Minahasa Tenggara. Hasil pemeriksaan tersebut memuat Opini "Tidak Memberikan Pendapat" atau Disclaimer Opinion. Permasalahan secara garis besar dalam Laporan Hasil Pemeriksaan tersebut adalah sebagai berikut.

a. Penyajian Kas Daerah yang belum didukung dokumen pendukung yang memadai terhadap setiap mutasi dari Kas Daerah tersebut. Selain itu terdapat penyajian Kas di Bendahara Pengeluaran yang tidak sesuai dengan pengertian Kas dimana merupakan Aset Lancar yang "dimiliki dan dikuasi" pada tanggal Neraca.

b. Penyajian Piutang Lain-lain yang belum didukung dengan dokumen memadai sebagaimana Buletin Teknis Nomor 6 tentang Akuntansi Piutang. Piutang tersebut belum didukung Surat Keterangan Tanggung jawab Mutlak (SKTJM). 
c. Penyajian Persediaan pada Neraca TA 2011belum mengkomodir Persediaan dari enam SKPD.

d. Penyajian Aset Tetap pada Neraca TA 2010 belum menggambarkan kondisi sebenarnya dimana perbedaan antar data pendukung, penguasaan aset yang tidak semestinya dan dokumen kepemilikan aset.

e. Penyajian Utang Jangka Pendek Lainnya pada Neraca TA 2011 yang belum didukung bukti transaksi yang memadai sebesar serta terdapat mutasi pengurang Utang Jangka Pendek Lainnya yang belum dijelaskan.

Berdasarkan beberapa catatan dari Laporan Hasil Pemeriksaan LKPD TA 2011 tersebut, diantaranya merupakan permasalahan yang berulang. Selain itu terdapat beberapa permasalahan yang telah diungkap pada Laporan Hasil Reviu LKPD TA 2011 Inspektorat berupa permasalahan pencatatan dan pengungkapan pada CaLK terkait akun Kas, Piutang dan Aset Tetap. Namun dikarenakan pelaksanaan reviu yang sudah terlambat dan waktu pelaksanaan reviu yang terbatas maka saran perbaikan Inspektorat belum dapat dilakukan sepenuhnya oleh Pemerintah Daerah khususnya DPPKAD.

Salah satu saran hasil reviu Inspektorat adalah DPPKAD diharuskan menelusur kembali pencatatan Aset dan Utang PFK. Hal ini menyulitkan DPPKAD mengingat waktu yang dibutuhkan penelusuran cukup lama sementara DPPKAD diharuskan segera menyelesaikan penyusunan LKPD untuk selanjutnya diserahkan BPK RI. LKPD hasil pemeriksaan BPK RI tersebut menjadi dokumen pertanggungjawaban Kepala Daerah kepada DPRD Kabupaten Minahasa Tenggara.

Berdasarkan pembahasan melalui analisa dan evaluasi atas pelaksanaan Reviu Laporan Keuangan Pemerintah Daerah Kabupaten Minahasa Tenggara Tahun Anggaran 2010 dan Tahun Anggaran 2011 dapat dirangkum sebagai berikut.

Data Hasil Analisa dam Evaluasi Pelaksanaan Reviu LKPD TA 2010 dan 2011

\begin{tabular}{|c|c|c|c|c|}
\hline No & Tahap Reviu & Standar & Pelaksanaan & Keterangan \\
\hline \multicolumn{5}{|c|}{ Tahun Anggaran 2010} \\
\hline \multirow[t]{3}{*}{1} & \multirow[t]{3}{*}{ Perencanaan } & a. Pemahaman Entitas & $\begin{array}{l}\text { Belum dapat dilakukan } \\
\text { sepenuhnya karena Pemda } \\
\text { belum memiliki Perbup } \\
\text { tentang Sisdur dan Perbup } \\
\text { Kebijakan Akuntansi dan } \\
\text { Pelaporan }\end{array}$ & $\begin{array}{l}\text { Belum } \\
\text { terpenuhi }\end{array}$ \\
\hline & & b. Penilaian SPI & $\begin{array}{l}\text { Belum dapat dilakukan } \\
\text { sepenuhnya dikarenakan } \\
\text { keterbatasan SDM dan } \\
\text { jumlah Hari waktu reviu }\end{array}$ & $\begin{array}{l}\text { Belum } \\
\text { terpenuhi }\end{array}$ \\
\hline & & $\begin{array}{ll}\text { c. Penyusunan Program Kerja } \\
\text { Perorangan (PKP) }\end{array}$ & Belum dilaksanakan & $\begin{array}{l}\text { Belum } \\
\text { terpenuhi }\end{array}$ \\
\hline \multirow[t]{2}{*}{2} & \multirow[t]{2}{*}{ Pelaksanaan } & $\begin{array}{llr}\text { a. } & \text { Secara Paralel } & \text { Dengan } \\
& \text { Penyusunan LKPD } & \end{array}$ & $\begin{array}{l}\text { Belum dilaksanakan (Reviu } \\
\text { setelah selesai penyusunan } \\
\text { LKPD) }\end{array}$ & $\begin{array}{l}\text { Belum } \\
\text { terpenuhi }\end{array}$ \\
\hline & & $\begin{array}{l}\text { b. Paling lambat bulan Februari } \\
\text { Tahun berikutnya }\end{array}$ & $\begin{array}{l}\text { Belum dilaksanakan (Reviu } \\
\text { dilaksanakan bulan Juni } \\
\text { tahun berikutnya) }\end{array}$ & $\begin{array}{l}\text { Belum } \\
\text { terpenuhi }\end{array}$ \\
\hline
\end{tabular}




\begin{tabular}{|c|c|c|c|c|}
\hline No & Tahap Reviu & Standar & Pelaksanaan & Keterangan \\
\hline & & $\begin{array}{l}\text { c. Pemenuhan Tim Reviu yang } \\
\text { Memadai }\end{array}$ & $\begin{array}{l}\text { Belum terpenuhi (SDM } \\
\text { yang ada masih kurang dan } \\
\text { latar belakang akuntan } \\
\text { masing minim) }\end{array}$ & $\begin{array}{l}\text { Belum } \\
\text { terpenuhi }\end{array}$ \\
\hline \multirow[t]{2}{*}{3} & Pelaporan & $\begin{array}{l}\text { a. Penyusunan dan Penyampaian } \\
\text { Laporan Hasil Reviu }\end{array}$ & Telah dilaksanakan & $\begin{array}{l}\text { Telah } \\
\text { terpenuhi }\end{array}$ \\
\hline & & b. Pernyataan Telah Direviu & Telah dilaksanakan & $\begin{array}{l}\text { Telah } \\
\text { terpenuhi }\end{array}$ \\
\hline \multicolumn{5}{|c|}{ II. Tahun Anggaran 2011} \\
\hline \multirow[t]{3}{*}{1} & \multirow[t]{3}{*}{ Perencanaan } & a. Pemahaman Entitas & $\begin{array}{l}\text { Belum dapat dilakukan } \\
\text { sepenuhnya karena Pemda } \\
\text { belum memiliki Perbup } \\
\text { tentang Sisdur dan Perbup } \\
\text { Kebijakan Akuntansi dan } \\
\text { Pelaporan }\end{array}$ & $\begin{array}{l}\text { Belum } \\
\text { terpenuhi }\end{array}$ \\
\hline & & b. Penilaian SPI & $\begin{array}{l}\text { Belum dapat dilakukan } \\
\text { sepenuhnya dikarenakan } \\
\text { keterbatasan SDM dan } \\
\text { jumlah Hari waktu reviu }\end{array}$ & $\begin{array}{l}\text { Belum } \\
\text { terpenuhi }\end{array}$ \\
\hline & & $\begin{array}{ll}\text { c. Penyusunan Program Kerja } \\
\text { Perorangan (PKP) }\end{array}$ & Belum dilaksanakan & $\begin{array}{l}\text { Belum } \\
\text { terpenuhi }\end{array}$ \\
\hline \multirow[t]{3}{*}{2} & \multirow[t]{3}{*}{ Pelaksanaan } & $\begin{array}{llr}\text { a. } & \text { Secara Paralel } & \text { Dengan } \\
& \text { Penyusunan LKPD }\end{array}$ & $\begin{array}{l}\text { Belum dilaksanakan (Reviu } \\
\text { setelah selesai penyusunan } \\
\text { LKPD) }\end{array}$ & $\begin{array}{l}\text { Belum } \\
\text { terpenuhi }\end{array}$ \\
\hline & & $\begin{array}{l}\text { a. Paling lambat bulan Februari } \\
\text { Tahun berikutnya }\end{array}$ & $\begin{array}{l}\text { Belum dilaksanakan (Reviu } \\
\text { dilaksanakan bulan Juli } \\
\text { tahun berikutnya) }\end{array}$ & $\begin{array}{l}\text { Belum } \\
\text { terpenuhi }\end{array}$ \\
\hline & & $\begin{array}{l}\text { b. Pemenuhan Tim Reviu yang } \\
\text { Memadai }\end{array}$ & $\begin{array}{l}\text { Belum terpenuhi (SDM } \\
\text { yang ada masih kurang dan } \\
\text { latar belakang akuntan } \\
\text { masing minim) }\end{array}$ & $\begin{array}{l}\text { Belum } \\
\text { terpenuhi }\end{array}$ \\
\hline \multirow[t]{2}{*}{3} & \multirow[t]{2}{*}{ Pelaporan } & $\begin{array}{l}\text { a. Penyusunan dan Penyampaian } \\
\text { Laporan Hasil Reviu }\end{array}$ & Telah dilaksanakan & $\begin{array}{l}\text { Telah } \\
\text { terpenuhi }\end{array}$ \\
\hline & & b. Pernyataan Telah Direviu & Telah dilaksanakan & $\begin{array}{l}\text { Telah } \\
\text { terpenuhi }\end{array}$ \\
\hline
\end{tabular}

Sumber: Hasil Olah Data

\section{KESIMPULANDAN SARAN \\ 1. Kesimpulan}

Berdasarkan hasil Analisa Dampak Reviu Inspektorat Terhadap Kualitas Akuntabilitas Laporan Keuangan Pemerintah Daerah (LKPD) Kab Minahasa Tenggara TA 2010 dan 2011, penulis dapat mengambil kesimpulan sebagai berikut.

a. Mekanisme Reviu atas LKPD Kabupaten Minahasa Tenggara TA 2010 dan TA 2011 belum sesuai dengan Pedoman Pelaksanaan Reviu yang tertuang dalam Peraturan Menteri Dalam 
Negeri Nomor 4 Tahun 2008 tentang Pedoman Pelaksanaan Reviu LKPD. Hal ini disebabkan belum adanya perencanaan reviu yang memadai, pelaksanaan reviu yang tidak sesuai jadwal, metode pelaksanaan reviu yang belum mengacu pada pedoman pelaksanaan reviu serta dukungan sumber daya manusia dengan latar belakang pendidikan yang belum memadai pada Inspektorat.

b. Dampak Reviu Inspektorat dalam meningkatkan akuntabilitas LKPDKabupaten Minahasa Tenggara TA 2010 dan TA 2011 belum dapat terealisasi. Hal ini dapat diketahui dengan opini hasil pemeriksaan BPK RI atas LKPD TA 2010 dan TA 2011 masih belum meningkat. Opini BPK RI atas LKPD TA 2010 dan TA 2011 adalah Tidak Menyatakan Pendapat (Disclaimer Opinion). Akuntabilitas LKPD tersebut bukan tanggung jawab Inspektorat melainkan seluruh elemen di lingkungan Pemerintah Daerah namun Inspektorat memiliki peran penting dalam mewujudkan akuntabilitas keuangan daerah.

c. Inspektorat belum menetapkan langkah-langkah konkrit untuk meningkatkan kualitas akuntabilitas Keuangan Daerah. Kegiatan Inspektorat lebih bersifat rutinitas seperti tahun sebelumnya tanpa adanya monitoring kegiatan yang sudah dilakukan untuk menjadi bahan menentukan langkah-langkah kegiatan di periode yang akan datang.

\section{Saran}

Berdasarkan hasil Analisa Dampak Reviu Inspektorat Terhadap Kualitas Akuntabilitas LKPD Kabupaten Minahasa Tenggara TA 2010 dan 2011, penulis dapat memberikan saran perbaikan, diantaranya sebagai berikut.

a. Pemerintah Daerah agar melakukan pendidikan dan pelatihan Peraturan Menteri Dalam Negeri Nomor Nomor 4 Tahun 2008 tentang Pedoman Pelaksanaan Reviu LKPD dan meningkatkan kemampuan pegawai Inspektorat melalui pelatihan-pelatihan dalam melaksanakan reviu LKPD. Agar dapat meningkatkan peran APIP, Pemerintah Daerah dapat berkoordinasi dengan Instansi Pembina APIP baik Inspektorat Jenderal Departemen Dalam Negeri maupun Badan Pengawasan Keuangan dan Pembangunan (BPKP).

b. Inspektorat agar berkoordinasi dengan Badan Kepegawaian Daerah (BKD) dalam menentukan analisis data pegawai dan kebutuhan pegawai yang dapat mendukung kinerja Inspektorat. Hasil analisa tersebut dapat disampaikan kepada Kepala Daerah sebagai pertimbangan dalam melakukan usulan mutasi pegawai maupun rekruitment PNS.

c. Inspektorat agar berkoordinasi dengan Dinas Pengelolaan Pendapatan Keuangan dan Aset Daerah (DPPKAD) dalam hal mengidentifikasi permasalahan yang menjadi penyebab LKPD TA 2010 dan 2011 memperolah opini disclaimer dari BPK RI. Koordinasi tersebut dapat pula dilakukan oleh Pemerintah Daerah Kabupaten Minahasa Tenggara dengan BPK-RI. Hasil identifikasi permasalahan tersebut menjadi point penting atau prioritas permasalahan yang akan dicari jalan keluar untuk dilakukan perbaikan.

\section{DAFTAR PUSTAKA}

Abdul Halim, 2002, Seri Akuntansi Sektor Publik-Akuntansi Keuangan Daerah, Jakarta, Salemba Empat

Abdul Halim, 2007, Pengelolaan Keuangan Daerah, Yogyakarta, Salemba Empat

Bupati Minahasa Tenggara, 2011, Peraturan Bupati Minahasa Tenggara Nomor 06e Tahun 2011 tentang Perubahan Pertama Peraturan Bupati Minahasa Tenggara Nomor 5 Tahun 2009 tentang Penjabaran Tugas Pokok dan Fungsi Inspektorat Kabupaten Minahasa Tenggara

BPK RI, 2010, Siaran Pers: BPK dan APIP Tingkatkan Sinergi "Peningkatan Transparansi dan Akuntabilitas Keuangan Negara"

BPK RI, 2011, IHPS Semester II Tahun 2010, Jakarta, BPK RI 
BPK RI, 2012, IHPS Semester II Tahun 2011, Jakarta, BPK RI

Direktur Jenderal Perbendaharaan, 2006, Peraturan Direktur Jenderal Perbendaharaan Nomor PER-44/PB/2006 tentang Pedoman Pelaksanaan Reviu Laporan Keuangan Kementerian Negara/Lembaga

Inspektur Minahasa Tenggara, 2011, Laporan Hasil Reviu Inspektorat atas Laporan Keuangan Kabupaten Minahasa Tenggara Tahun Anggaran 2010

Inspektur Minahasa Tenggara, 2012, Laporan Hasil Reviu Inspektorat atas Laporan Keuangan Kabupaten Minahasa Tenggara Tahun Anggaran 2011

Kuntadi, Cris. 2010. Peningkatan Kapasitas Auditor Internal dalam Pelaksanaan Reviu Atas Laporan Keuangan

Mardiasmo, 2002, Akuntansi Sektor Publik, Penerbit Andi, Yogyakarta

Menteri Dalam Negeri, 2008, Peraturan Menteri Dalam Negeri No 4 tahun 2008 tentang Pedoman Pelaksanaan Reviu atas Laporan Keuangan Pemerintah Daerah

Menteri Pemberdayaan Aparatur Negara, 2008, Peraturan Menteri Pemberdayaan Aparatur Negara Nomor PER/05/M.PAN/03/2008 tanggal 31 Maret 2008 tentang Standar Audit APIP

Pemerintah Kabupaten Minahasa Tenggara, 2009, "Selayang Pandang Dua Tahun (23 Mei 2007 s.d. 23 Mei 2009) Perjalanan Pemerintahan Kabupaten Minahasa Tenggara dan Delapan Bulan (24 September 2008 s.d. 23 Mei 2009) Keberhasilan Kepemimpinan T2-JaDi"

Republik Indonesia, 2003, Undang-Undang Republik Indonesia Nomor 17 Tahun 2003 tentang Keuangan Negara

, Undang-Undang Republik Indonesia Nomor 1 Tahun 2004 tentang Perbendaharaan Negara , Undang-Undang Republik Indonesia Nomor 15 Tahun 2004 tentang Pemeriksaan Pengelolaan dan Tanggung Jawab Keuangan Negara Pemerintahan , Peraturan Pemerintah RI Nomor 24 Tahun 2005 tentang Standar Akuntansi

, Peraturan Pemerintah RI Nomor 8 Tahun 2006 tentang Pelaporan Keuangan dan Kinerja Instansi Pemerintah , Peraturan Pemerintah Republik Indonesia Nomor 60 Tahun 2008 tentang Sistem Pengendalian Intern Pemerintah

Sugijanto, Robert Gunadi H, dan Soni Loho, 1995, Akuntansi Pemerintahan dan Organisasi Nirlaba, Malang : PPA-FE Universitas Brawijaya 